\title{
ICE AVALANCHES: SOME EMPIRICAL INFORMATION ABOUT THEIR FORMATION AND REACH
}

\author{
By JÜRG ALEAN
}

(Versuchsanstalt für Wasserbau, Hydrologie und Glaziologie, ETH-Zentrum, CH-8092 Zürich, Switzerland)

ABSTRACT. A study intended to be mainly of practical use in the prediction of ice-avalanche hazards was carried out. About 100 ice avalanches, mostly from the Alps, were documented. Starting zones of these ice avalanches could be classified by using simple terrain characteristics. Ice avalanches from some starting zones at relatively low altitudes and with large, homogeneously inclined bedrock planes occur predominantly in summer and autumn. No such seasonal variation in frequency was found in connection with other types of starting zones occurring either at higher altitudes or involving abrupt changes of the bedrock's gradient. One- and two-parameter models for the estimation of run-out distances of landslides and snow avalanches were tested for their use with ice avalanches. Introduction of the second ( $v^{2}$ proportional) frictional parameter leads only to moderately improved accuracy in the prediction of run-out distances. For relatively short run-out distances (several hundred meters), an alternative method of estimation, based on terrain characteristics, is proposed.

RÉSUMÉ. Avalanches de glace: quelques informations empiriques sur leur formation et leur portée. Il a été fait une étude qui se veut être d'utilité pratique dans la prédiction d'avalanches de glace. Environ 100 avalanches, la plupart dans les Alpes, ont été analysées. Les zones de rupture de ces avalanches de glace ont pu être classées en utilisant de simples caractéristiques du terrain. Des avalanches, qui ont leur origine en assez basse altitude et dont la surface de rupture repose sur de larges plaques rocheuses uniformément inclinées, tombent principalement en été et en automne. Il n'a pas été possible de trouver une telle variation saisonnière des fréquences pour les zones de

\section{INTRODUCTION}

Ice avalanches occur when ice breaks off a steep glacier. Under the influence of gravity the ice plunges down-slope, is progressively shattered into smaller and smaller pieces, and stops when frictional forces have completely destroyed its kinetic energy.

In the Alps, ice avalanches occur less frequently and in fewer locations than snow avalanches. Nevertheless, at least 124 people were killed in ice avalanches between 1901 and 1983 in the Swiss Alps alone. The most catastrophic events known in Switzerland were the destruction of a whole village near the Simplon Pass in 1597 (81 killed; Coaz, 1910) and of worker camps at the construction site of the Mattmark dam (Valais) in 1965 (88 killed; Röthlisberger, 1978; Röthlisberger and Kasser, 1978). Accidents due to ice avalanches have become frequent occurrences on glaciers as a result of rapidly increasing tourist and climbing activity. In 1983, five accidents occurred in Alpine areas, constituting a total of ten lives lost - nine on glacier surfaces and one below a steep glacier tongue (Alean, 1984).

Ice avalanches are known to have dammed streams so that lakes formed temporarily. Subsequent floods caused extensive damage and the loss of many lives (Röthlisberger, 1978; Haeberli, 1983).

Primarily as a result of intensive development of tourism and the installation of facilities for hydro-electric power stations, the evaluation of ice-avalanche hazards has rupture situées en plus haute altitude ou composées d'un lit rocheux plus tourmenté. Des modèles à un et deux paramètres, faits pour estimer les distances d'arrêt d'avalanches de neige et de glissements de terrain, ont été testés pour les avalanches de glace. Même l'introduction du deuxième paramètre de friction (proportionel à $v^{2}$ ) n'a amené qu'une précision modeste dans la prévision des distances d'arrêt. Il est proposé une méthode alternative, basée sur les caractéristiques du terrain, pour prévoir des distances d'arrêt assez courtes (quelques centaines de mètres).

ZUSAMMENFASSUNG. Eislawinen: Erfahrungswerte $z u$ ihrer Entstehung und Reichweite. Die vorliegende Studie soll vorwiegend von praktischem Nutzen bei der Beurteilung von Risiken im Zusammenhang mit Eislawinen (Gletscherstürzen) sein. Rund 100 Eislawinen, vorwiegend aus den Alpen, wurden dokumentiert. Ihre Anrissgebiete konnten mit Hilfe einfacher Geländeparameter klassifiziert werden. Eislawinen aus Anrissgebieten in verhältnismässig geringer Meereshöhe und mit grossen, gleichmässig geneigten Felsbettpartien gehen vorwiegend im Sommer und Herbst nieder. Keine derartige Variation der saisonalen Hăufigkeit konnte im Zusamenhang mit anderen Anrisszonen gefunden werden, die sich entweder in grösserer Höhe oder über markanten Gefällsstufen des Felsuntergrundes befinden. Ein- und Zweiparametermodelle zur Schătzung von Reichweiten von Bergstürzen und Schneelawinen wurden auf ihre Anwendbarkeit auf Eislawinen geprüft. Die Einführung des zweiten, $v^{2}$-proportionalen Reibungsterms führte nur zu einer bescheidenen Verbesserung der Reichweitenprognosen. Bei relativ kurzen Reichweiten (einige hundert Meter) wird die Anwendung einer anderen Schätzmethode auf der Basis einfacher Sturzbahnparameter vorgeschlagen.

become an important and recurring task of applied glaciology in the Alps.

The aim of this study was to seek empirical information on (a) the conditions of formation, (b) the possible annual variation in the frequency of occurrence, and (c) the reach (run-out distances) of ice avalanches. Simple but reliable rules were sought which it is hoped would be of use when ice-avalanche hazards have to be assessed. Existing models of flowing snow avalanches were used in order to test their use in predicting ice-avalanche run-out distances. Developing new dynamic models was beyond the scope of this study.

\section{THE DATA BASE}

Quantitative information on a few ice avalanches has been published by Capello (1959), Coaz (1910), Glaister (1951), Heim (1896), and Röthlisberger (1978). The events at Huascaràn, Peru, in 1962 and 1970 were described and analysed by various authors (e.g. Morales, 1966; Lliboutry, 1975; Körner, 1983; Schneider, 1983; Stadelmann, 1983; Welsch, 1983). The ice which broke off Huascaràn had been mixed with a considerable amount of rock debris and water by the time it reached the lower slopes of the mountain Therefore, these events may have characteristics different from those of "normal" ice avalanches.

Starting zones, avalanche paths, and deposits (terminology cf. Fig. 5) were mapped on the basis of (a) published 
information (five avalanches), (b) vertical aerial photographs (84 avalanches), (c) oblique aerial photographs (five avalanches), and field measurements (five avalanches). Three of these avalanches had occurred in Alaska, one on Mount Baker, Washington, U.S.A., and all others in the Alps. Topographical maps at a scale of 1: 10000 could be used when plotting most of the 92 ice avalanches in the Swiss Alps. Most aerial photographs had a similar scale.

The smallest ice avalanches recorded from aerial photographs have volumes of $500-1000 \mathrm{~m}^{3}$. Most of the documented avalanches have volumes ranging from $10^{4}$ to $10^{6} \mathrm{~m}^{3}$. Only eight ice avalanches are known with volumes greater than $10^{6} \mathrm{~m}^{3}$. The biggest "pure" ice avalanche was recorded by L. Mayo (USGS, Fairbanks) on Mount Iliamna, Alaska $\left(2 \pm 1 \times 10^{7} \mathrm{~m}^{3}\right)$. Maps of some of these avalanches, together with numerical parameters of all of them, were published by Alean (1984). In addition, about 100 avalanches were found on photographs taken by automatic cameras aimed at glaciers which frequently produce small ice avalanches. These were only roughly analysed in terms of volume and time of occurrence (Alean, 1984, 1985).

\section{STARTING ZONES}

When assessing ice-avalanche hazards in a glacierized area, it must be known whether ice can break off a certain glacier or not. If run-out distances are to be estimated, the volume of the falling ice mass must be known (exceptions: see section 4.4). However, since run-out distances increase very moderately if avalanche volumes are, for example, doubled or tripled, only rough predictions of volumes are needed. Given (a) the uncertainties in the models used for run-out predictions and (b) the relatively rapid changes of the mass distribution of the ice in the starting zone, a reasonable accuracy required for volume estimations might be a factor of 3 to 5 .

Röthlisberger (1978) has discussed the stablizing factors which prevent a steep ice body from sliding off a mountainside, such as adhesion at the glacier bed, lateral support on channel-shaped beds, and support by parts which are frozen to the glacier bed. He particularly pointed out the difficulty in assessing the relative importance of these factors. The difficulty of predicting the stability of a steep glacier is illustrated by the example of Allalingletscher (Valais); after releasing the catastrophic avalanche at Mattmark, the glacier re-advanced but did not produce any more big avalanches (Röthlisberger and Kasser, 1978).
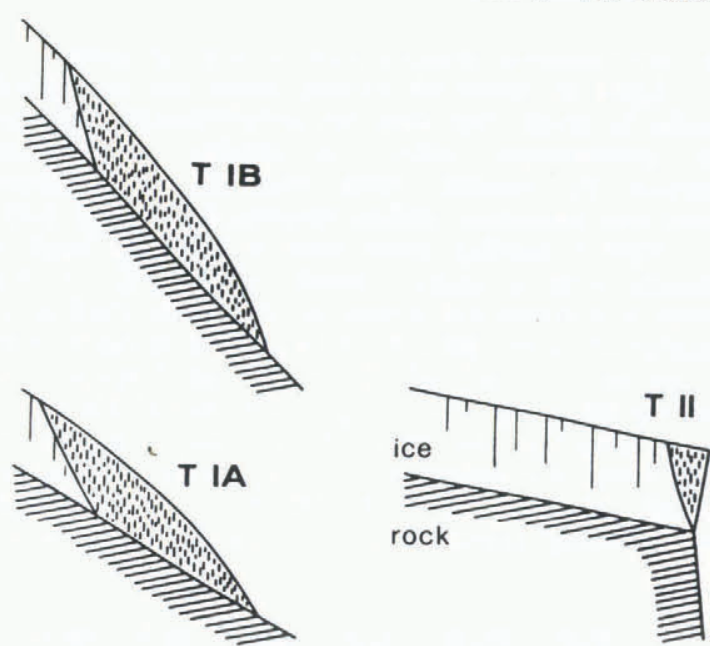

Fig. 1. Idealized types of starting zones. Most or all of the ice in the type IB starting zone is frozen to the bedrock (high altitude); most or all of the ice near the bedrock of the type IA starting zone is at the pressure melting-point (lower altitude). Dotted: ice expected to break off; hatched: bedrock.

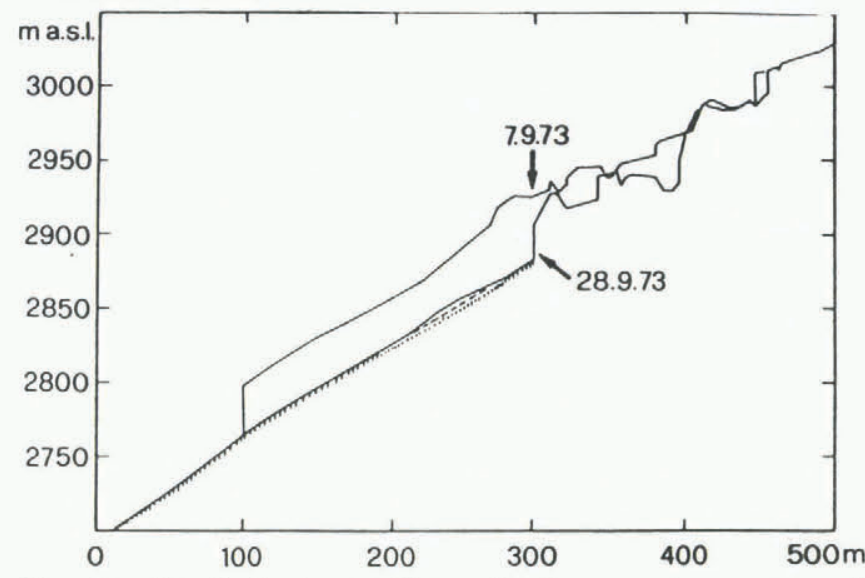

Fig. 2. Longitudinal profiles of the starting zone of Balmhorngletscher before and after the large ice avalanche of 1973. Vertical hatching shows known sections of the glacier bed (photogrammetry by Flotron, Meiringen).

TABLE I. DIMENSIONS OF SOME TYPE I STARTING ZONES

Glacier

Country Date of

avalanche

$\begin{array}{cccc}\text { Length } & \text { Width } & \begin{array}{c}\text { Average ice } \\ \text { thickness }\end{array} & \begin{array}{c}\text { Horizontal } \\ \text { surface area } \\ \mathrm{m}\end{array} \\ \mathrm{m} & \begin{array}{c}\mathrm{m} \\ \mathrm{m}^{4} \mathrm{~m}^{2}\end{array}\end{array}$

m

$\begin{array}{cc}\sim 300 & 330 \\ 450 & 600 \\ 520 & 360 \\ ? & 500 \\ 335 & 220 \\ 1000 & 760\end{array}$

Switzerland 30 Aug. 1965

Switzerland 11 Sep. 1895

Switzerland 28 Sep. 1973

Altels (1)

Balmhorn

Bockkarkees

Fletschhorn

Iliamna

Austria

$5 / 6$ Oct. 1979

Switzerland Sep. 1979

Alaska

(3)

Volume

Average altitude $\mathrm{m}$ a.s.1.
Average slope of bedrock deg

Type $I B$

Bis (Weisshorn) Switzerland (7)

1977

$150 \quad 260$

20

5
18
7
11
3
57

$\begin{array}{cc}1 & 2500 \\ 4.5 & 3200 \\ 2 & 2800 \\ 3 & 2750 \\ 1 & 3250 \\ 11(4) & (5)\end{array}$

(1) Heim (1896).

(2) Personal communication from H. Slupetzky.

(3) Before 25 August (date of photogtraph).

(4) Volume of ice as determined in starting zone; deposit considerably larger $\left(2-3 \times 10^{7} \mathrm{~m}^{3}\right)$, possibly due to snow entrainment and loosening of material.

(5) $2000 \mathrm{~m}$ a.s.1.; since this mountain is situated in a different climatic region, the altitude cannot be compared directly to the other values.

(6) Sliding surface is ice or dense firn.

(7) Before 14 July (date of photograph).

(8) Large inaccuracy; range $0.5-2 \times 10^{6} \mathrm{~m}^{3}$. 


\subsection{Morphological classification of starting zones}

Types of idealized starting zones can be identified. It should be noted that these are simplifications and that there are intermediate types. A similar classification was proposed by Haefeli (1966), who did not associate these types with maximum release volumes (cf. section 3.3).

Type I starting zones have a relatively large area of bedrock with a fairly constant slope (Fig. 1). Figure 2 shows a longitudinal profile of the main starting zone on Balmhorngletscher (Bernese Alps) which produced avalanches of up to $2 \times 10^{6} \mathrm{~m}^{3}$. Table I gives dimensions of such starting zones and the average inclination of the rock bed.

Apparently, the inclination of glacier beds from which type I ice avalanches can slide or break off increase with altitude (cf. Fig. 3). Röthlisberger (1978) has pointed out the stabilizing effect of cold ice frozen to the glacier bed.

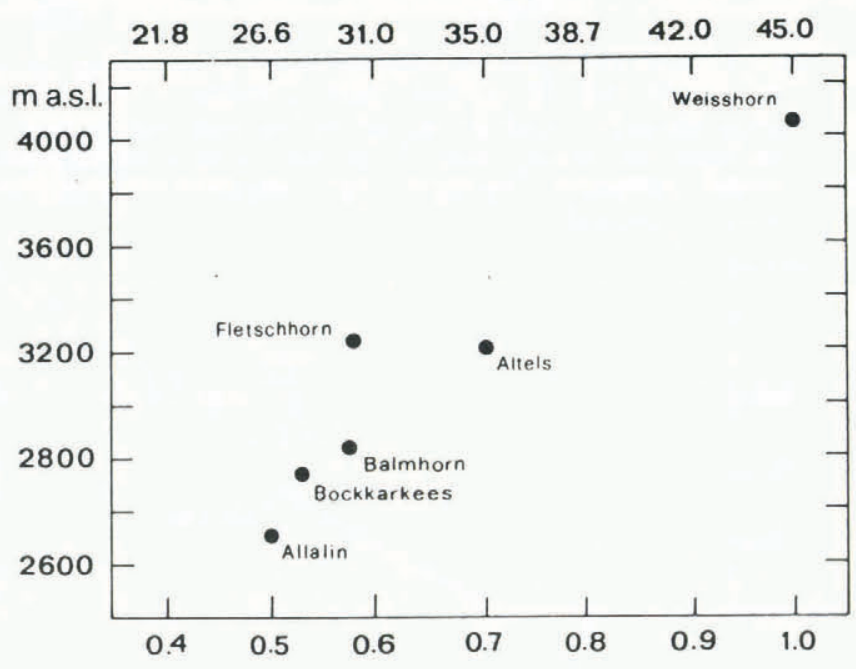

Fig. 3. Relationship between slope of bedrock in type I starting zones and the average altitude above sea-level. The upper abscissa is in degrees and the lower gives the tangent of the slope.

This increase in the inclination of starting zones with altitude seems to be possible because the larger parts of the ice mass are frozen to the bedrock. Indeed, the rupture surface on Fletschhorngletscher (Valais; average altitude of starting zone: $3250 \mathrm{~m}$ ) is partially intraglacial, and only about half the ice slides directly off the bedrock (Alean, 1984). On the other hand, practically the whole starting zone of Balmhorngletscher, as shown in Figure 2, is on bedrock. At an average altitude of only $2850 \mathrm{~m}$ a.s.l., it probably features little or no ice which is frozen to the bed.

Such high hanging glaciers as those on the northeasterly exposed face of the Weisshorn are probably cold throughout (Haeberli, 1976; Haeberli and Alean, 1985). Ice from these hanging glaciers was observed to break off from mostly intraglacial rupture planes even steeper than the $45^{\circ}$ inclination of the bedrock (Röthlisberger, 1978; Alean, 1984). Thus, type I starting zones can be subdivided: those with most of the ice frozen to the bedrock are classified as type IB, and those with little or no ice frozen to the bedrock as type IA.

It is important to realize that many Alpine glaciers have beds which must be, in some parts, considerably steeper than the inclination of type I (A and B) starting zones at a corresponding altitude and which are not known to have caused any ice avalanches. In some cases, the lower parts of such glaciers rest on less steeply inclined bedrock and support the steeper sections higher up. Since the stability of an ice mass is probably also affected by such factors as bedrock roughness, steps in the longitudinal profile, and lateral support, a simple determination of the average bedrock inclination cannot be expected to yield more than a very preliminary indication of a steep glacier's potential to produce ice avalanches. For safety reasons, bedrock roughness could not be determined in any starting zone. The role of melt water is discussed in section 3.2.

In type II starting zones, ice breaks off from an area of abrupt longitudinal change in the inclination of the bedrock (Fig. 4a and b). The glacier develops a near-vertical cliff, typically $30-50 \mathrm{~m}$ high, from which ice breaks off when the cliff becomes too steep or even overhanging. Such a starting zone at the lower end of the southern hanging glacier of the Mönch, Bernese Alps, has been intensively studied (Alean, 1984, 1985, in press; cf. also Fig. 10).

Ice avalanches may also be produced when seracs topple over. However, no very large volumes of ice have been observed to have been released in this way.

\subsection{Seasonal distribution of ice-avalanche occurrences}

Ice avalanches from the type IB starting zones at the Weisshorn have been recorded in all seasons (cf. Table II).
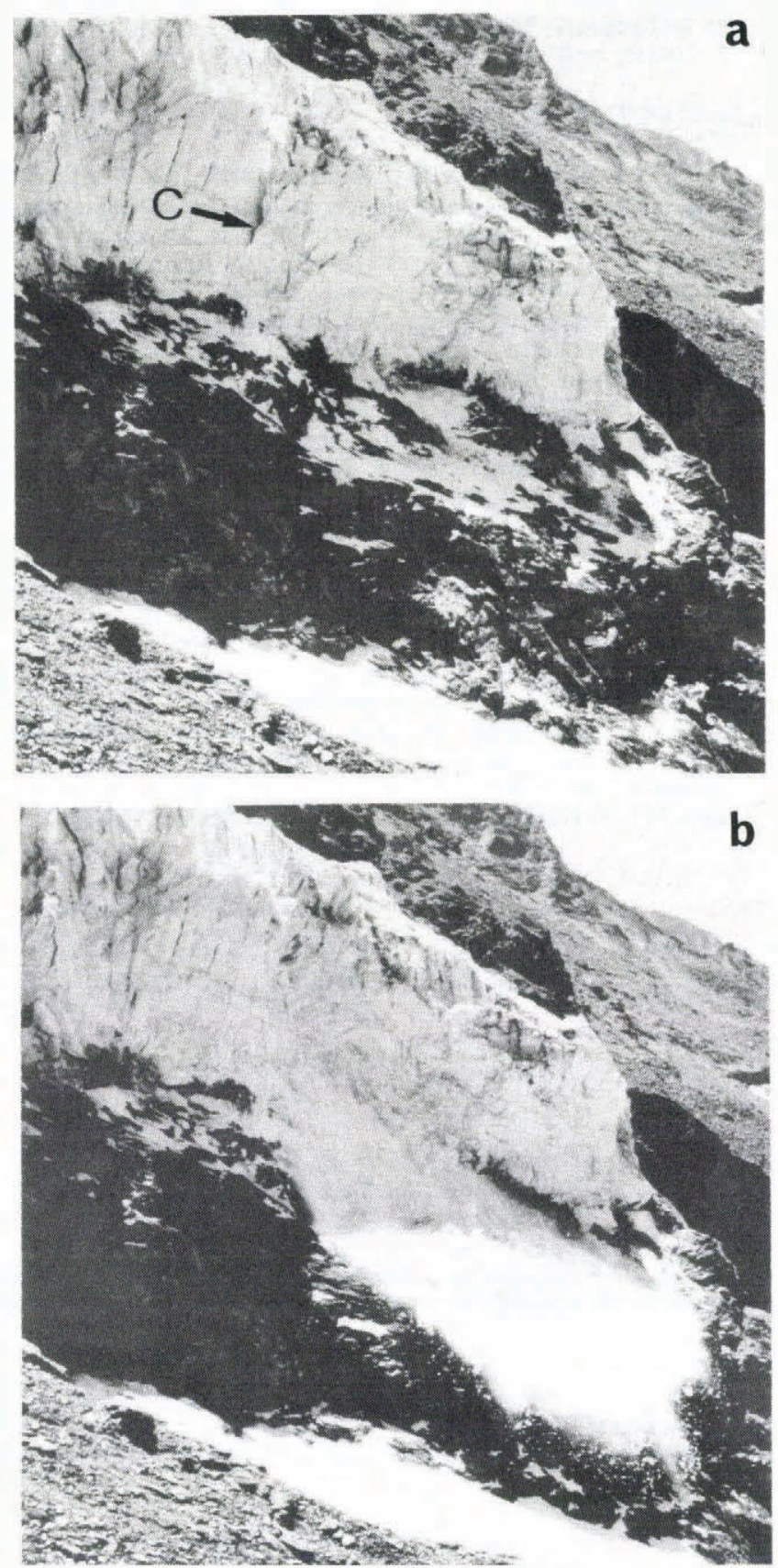

Fig. 4. Front of Festigletscher, Valais, Switzerland: type II starting zone. a. Immediately before; $b$. During the fall of a $2000 \mathrm{~m}^{3}$ ice mass: 18 August 1981, approximately $15.00 \mathrm{~h}$. The crevasse (C) behind the ice mass had become noticeably bigger during the last few minutes before the event. The vertical ice cliff is about $20-25 \mathrm{~m}$ high. 
TABLE II. SEASONAL DISTRIBUTION OF LARGE ICE AVALANCHES

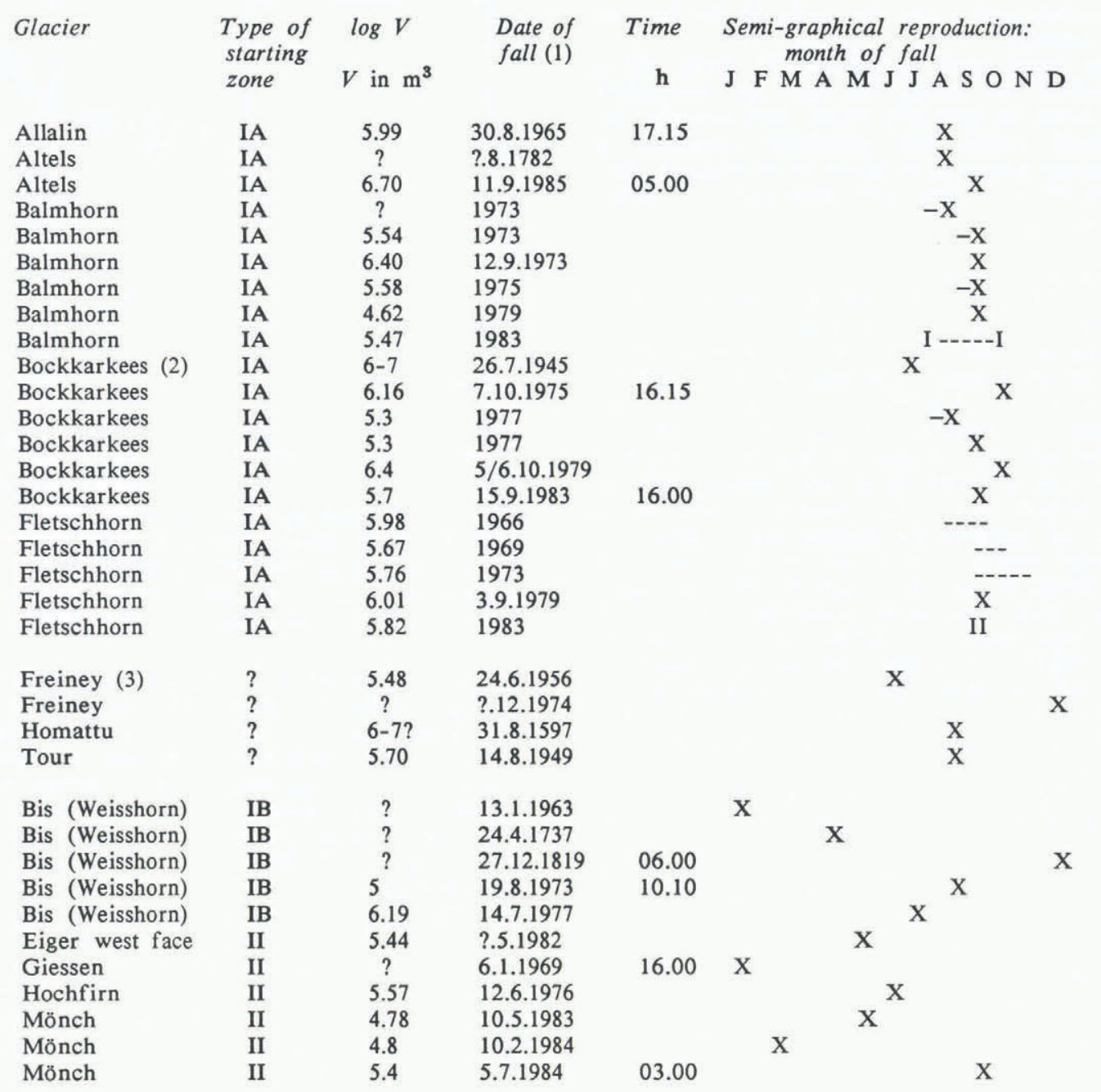

$V$ Volume of ice avalanche or combined volumes of all avalanches of one phase of activity.

(1) Only for individual avalanches (day, month, year).

(2) Data Bockkarkees: personal communication from H. Slupetzky; Slupetzky and others (1983).

(3) From Capello (1959).

$\mathrm{X}$ Date in this month.

-X Date in this month or a few weeks before.

I--I Phase of activity in these months.

--- Phase of activity in these months, possibly also before and after.

On the other hand, a clear seasonal distribution in the occurrence of large (volumes greater than $10^{5} \mathrm{~m}^{3}$ ) ice avalanches from starting zones of type IA is evident in Table II. Such avalanches seem to occur primarily between the months of July and October, inclusive; in other words, after the late spring/early summer maximum of ice velocities associated with increased water pressure at the glacier bed in partially or totally temperate Alpine glaciers (Iken, 1977, 1978; Aellen and Iken, 1979). This is also the time of year in which "surge-like behavior" of Allalingletscher was noted by Röthlisberger and Kasser (1978). Abundance of melt water may also reduce friction at the ice-bedrock interface in the starting zone.

It is noteworthy that some type IA starting zones have produced only one very large ice avalanche, together with several minor ones a short time before and/or after the main event (Altels, 1895; Glacier du Tour, 1949; probably Ghacciaio di Freiney, 1956; Allalingletscher, 1965). In other cases, many relatively minor ice avalanches have contributed in building up large deposits of up to $10^{6} \mathrm{~m}^{3}$ volume during what is termed a "phase of activity". Phases of activity occur with remarkable regularity every $2-3$ years at Fletschhorngletscher, presumably once enough ice has flowed from the accumulation area into the starting zone. Balmhorngletscher produced one dominant, very large ice avalanche in $1973\left(2 \times 10^{6} \mathrm{~m}^{3}\right)$. By contrast, in 1983, a phase of activity, monitored by automatic cameras, produced a series of much smaller ice avalanches between the end of July and early October. Although a total of $3 \times 10^{5} \mathrm{~m}^{3}$ of ice was released, probably no single avalanche was larger than $5 \times 10^{4} \mathrm{~m}^{3}$. Phases of activity and individual large ice avalanches seem to occur in the same months of the year.

Type II starting zones produced ice avalanches throughout the year (Table II; cf. Alean, 1985). The lack of seasonal variation in ice-avalanche activity from this type of starting zone is understandable if it is assumed that the dominant release mechanism originates from internal stress distribution within the ice body rather than from basal sliding off the bed.

Prediction of the actual dates of fall have been attempted (Rőthlisberger, 1978) on a type IB starting zone at the Weisshorn and on a small lamella about to calve into a marginal lake of Grubengletscher, a situation comparable to a type II starting zone (Haeberli, 1975; Haeberli and Röthlisberger, 1976; Iken, 1977). In both cases, the rate of ice-velocity increase served as a means of prediction. Such field measurements of ice velocity can be technically difficult or dangerous.

However, no other method of prediction has proved to be reliable. In particular, crevasse patterns seem deceptive, at least in some cases. Observations done with an automatic camera at Balmhorngletscher and regular direct observations 
at Fletschhorngletscher showed astonishingly few and unspectacular crevasses only a few days prior to the start of major phases of activity.

On the other hand, small amounts of ice broke off a few minutes before the release of two ice avalanches (volumes in the order of $2000 \mathrm{~m}^{3}$ ) which were directly observed. Such small events may sometimes constitute a warning that a larger avalanche is about to be released. Detailed descriptions of both events have been given by Alean $(1984$, p. $159,169-71)$.

\subsection{Maximum volumes released}

Rothlisberger (1978) estimated the maximum volume of ice about to fall off a high hanging glacier on the Weisshorn by analysing the ice-velocity distribution. If no such measurements are available, crevasse patterns might be expected to give some indication of the amount of ice which could break off. However, as has been pointed out, there may be relatively few crevasses even a short time before the time of fall. Observations at the southern hanging glacier of the Mönch show that crevasses cannot be a reliable indicator of subsequently released ice volumes; in May 1982, a large lamella with a volume of almost 3 x $10^{5} \mathrm{~m}^{3}$ had developed in the type II starting zone. However, rather than one large avalanche, dozens of relatively small ones broke off during the following 15 months (Alean, 1985). The largest one had a volume of only $6 \times 10^{4} \mathrm{~m}^{3}$. In June 1984, a remarkably similar lamella had developed again in the same location. This time most of the lamella fell down in a single event at about $03.00 \mathrm{~h}$ on 5 July 1984 (Alean, in press).

Nevertheless, the simple morphological classification of starting zones may yield rough upper limits of ice-avalanche volumes originating in a specific starting zone. The largest known ice avalanches are listed in Table I, together with some characteristics of their starting zones. The Huascaràn events are not included because the possibility cannot be ruled out that a rock-fall was the cause of release in 1962, and since a strong earthquake initiated the 1970 avalanche All known ice avalanches with volumes of one or more million $\mathrm{m}^{3}$ originated in starting zones of types IA or IB. In the Alps, only a few mountains are as high as the Weisshorn, and this may explain why only one avalanche as large as $10^{6} \mathrm{~m}^{3}$ from a type IB starting zone has been observed.

Large planes of bedrock (or even firn in the case of the Iliamna avalanche) with a homogeneous inclination allow the build-up of large ice masses before the fall. In type II starting zones, the ice is typically $30-50 \mathrm{~m}$ thick. Only a relatively narrow lamella of ice parallel to the cliff can break off. The lamella at the southern hanging glacier of the Mönch (described above) had a depth of about $50 \mathrm{~m}$ measured parallel to the ice flow and a width of about $230 \mathrm{~m}$. Lateral mechanical coupling probably limits the width of lamellae which can fall from wide hanging glaciers. All known ice avalanches from starting zones of type II had volumes of less than $4 \times 10^{5} \mathrm{~m}^{3}$.

\section{RUN-OUT DISTANCES}

4.1. Existing models of landslide and snow-avalanche motion

Ice avalanches can be imagined as masses of ice breaking up into smaller and smaller particles. These crash into each other and against the ground (Fig. $4 \mathrm{a}$ and b) and thereby acquire rounded shapes. In some deposits, particle diameters are up to $15 \mathrm{~m}$ (Fig. 10). Typical particle sizes, however, seem to be $0.1-1 \mathrm{~m}$. Particles in the deposits are often embedded in a matrix of sintered ice dust which must be a result of the particle collisions.

Ice avalanches may move down-slope in a fashion somehow comparable to dry flowing snow avalanches or, alternatively, landslides. Heim (1932) noticed that larger landslides usually cover larger distances on identical topography. He introduced the idea of an average slope angle of the avalanche path ( $\alpha$ averaged from the top of the starting zone to the furthest point of the deposit) as a simple parameter to describe the reach of a landslide (cf. Figure 5 , the horizontally measured reach is not a physically reasonable parameter since it is obviously strongly influenced by the gradient of the terrain). Simplifying the landslide as

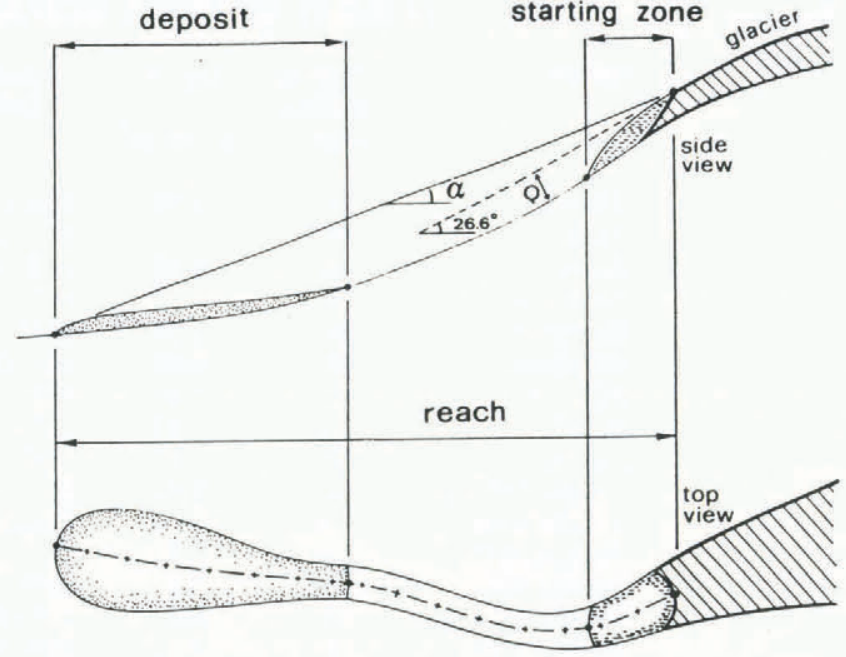

Fig. 5. Terminology used in describing ice avalanches. is the slope angle, measured along the avalanche track, from the top of the starting zone to the furthest point of the deposit. $Q$ is the maximum distance of the avalanche track to a line with slope $0.5\left(26.6^{\circ}\right)$.

a small rigid block and using Coulomb's law of dry friction, Müller (in Heim, 1932) showed that the tangent of the slope angle $(\alpha)$ can be considered to be equivalent to the frictional coefficient $\mu$ between the landslide and the track, if $\mu$ is assumed to be constant along the path. Various authors have tried to explain the surprisingly small friction displayed by large landslides (e.g. Shreve, 1966; Scheidegger, 1973; Hsü, 1975, 1978; Davies, 1982; Scheller, unpublished).

When modelling the reach of dry flowing snow avalanches, Voellmy (1955) first realized the need for an additional speed-dependent frictional parameter. In addition to $\mu$, the $v^{2}$ proportional "coefficient of turbulent friction" (६) was introduced. Salm (1966) modified this model slightly. Perla and others (1980; cf. also Körner, 1976, 1980, 1983) again used essentially the same equations but called the $v^{2}$ proportional parameter "mass to drag ratio", $M / D$. Scheiwiller and Hutter (1982, p. 85-86) pointed out that snow-avalanche motion is probably not "turbulent" in the sense of hydraulics; the $v^{2}$ proportional increase of friction is effected by mutual collisions of lumps of compressed snow.

Lied and Bakkehøi (1980) and Bakkehøi and others (1981, 1983) relied entirely on a statistical analysis of terrain parameters when predicting maximum snow-avalanche run-out distances. However, their statistical models clearly imply the effect of velocity-dependent friction.

\subsection{Analysis of ice-avalanche parameters}

In order to determine the applicability of a VoellmySalm-Perla-type model of snow-avalanche motion (incorporating velocity-independent and $v^{2}$-dependent frictional effects) to ice avalanches, all available parameters from 92 ice avalanches were statistically analysed. Details of this analysis were published by Alean (1984). The most important parameters of some large ice avalanches are given in Table III.

Before summarizing the results of the parameter analysis, the following points have to be emphasized: (a) some of the parameters have by no means a normal distribution and (b) the parameter "volume" in many cases is an upper limit rather than the actual amount of ice which broke off the glacier at one time. In some cases, a single event was clearly the dominant one and previous or subsequent falls were so small that they do not need to be considered (cf. section 3.2). However, in many cases the avalanche deposit was built up by a whole series of individual avalanches of comparable size occurring over a period of a few weeks, for example, at Balmhorngletscher in 1983 (Fig. 6) and at Fletschhorngletscher in 1983. Documentation of such sequential avalanches was possible at these two glaciers by means of an automatic camera (Balmhorn) and frequent field trips (Fletschhorn). At other 
TABLE III. PARAMETERS OF SOME LARGE ICE-AVALANCHE PATHS AND DEPOSITS

\begin{tabular}{|c|c|c|c|c|c|c|c|}
\hline $\begin{array}{c}\text { Glacier } \\
\text { name }\end{array}$ & $\begin{array}{l}\text { Avalanche } \\
\text { volume } \\
10^{6} \mathrm{~m}^{3}(1)\end{array}$ & $\begin{array}{c}\text { Tangent of } \\
\text { slope angle } \\
\alpha\end{array}$ & $\begin{array}{l}\text { Reach } \\
\qquad \mathrm{m}\end{array}$ & $\begin{array}{l}\text { Length of } \\
\text { deposit } \\
\text { m }\end{array}$ & $\begin{array}{c}\text { Maximum width } \\
\text { of deposit } \\
\mathrm{m}\end{array}$ & $\begin{array}{l}\text { Surface area } \\
\text { of deposit } \\
10^{4} \mathrm{~m}^{2}\end{array}$ & Date $(d, m, y)$ and remarks \\
\hline \multicolumn{8}{|l|}{ Swiss Alps } \\
\hline Allalin & 1.0 & 0.39 & 1430 & 1010 & 360 & 17 & 4.9.1965; 88 killed; one main fall \\
\hline Altels & $\underline{5.0}$ & $\underline{0.30}$ & 3900 & 1300 & 950 & 100 & 11.9.1895; 6 killed; one main fall \\
\hline Balmhorn & 2.5 & 0.51 & 2960 & 2470 & 440 & 40 & $? .9 .1973$ \\
\hline Balmhorn & 0.4 & 0.51 & 2600 & 2200 & 300 & 26 & $? .10 .1975$ \\
\hline Bis & 1.5 & 0.44 & 3040 & 2760 & 610 & 90 & $? .7 .1977$ \\
\hline Brunegg & 0.3 & 0.51 & 880 & 800 & 260 & 16 & 1971 \\
\hline Clariden & 0.2 & 0.57 & 1230 & 1220 & 280 & 18 & 1979 \\
\hline Eiger & 0.3 & 0.54 & 2330 & $?$ & 190 & 14 & ?.5.1982 \\
\hline Festi & 0.06 & $\underline{0.31}$ & 530 & 470 & 140 & 3 & 1971 \\
\hline Fletschhorn & 1.0 & 0.39 & 1430 & 1000 & 370 & 23 & 3.9 .1979 \\
\hline Gamchi & 0.6 & 0.56 & 1580 & 1090 & 300 & 20 & 1972 \\
\hline Hochfirn & 0.4 & 0.63 & $\underline{4160}$ & 1550 & 450 & 21 & 12.6.1976; 3 killed \\
\hline Mönch & 0.3 & $\underline{0.34}$ & 690 & 550 & 320 & 11 & 5.7 .1984 (cf. Alean, in press) \\
\hline Rossboden & 2.8 & 0.37 & $\underline{6100}$ & 1700 & $?$ & 70 & 19.3.1901; mixed ice/rock/snow \\
\hline Grindelwald(*) & 0.9 & 0.43 & 1380 & $?$ & 400 & 24 & 1982; *Lower Grindelwaldgletscher \\
\hline \multicolumn{8}{|l|}{ Alaska } \\
\hline Marvine (20 & 3.0 & $\underline{0.31}$ & 2600 & 2040 & 500 & 60 & ?.1983; perhaps after earthquake \\
\hline Iliamna (3) & $\underline{10-30}$ & $\underline{0.21}$ & $\underline{7800}$ & $\underline{5200}$ & $\underline{1900}$ & $\underline{560}$ & 1980 \\
\hline
\end{tabular}

(1) Volume values have accuracies in the range $\pm 10-70 \%$; for details cf. Alean (1984).

(2) East of Malaspina Glacier.

(3) From Iliamna volcano on to Red Glacier.

Extreme values are underlined.

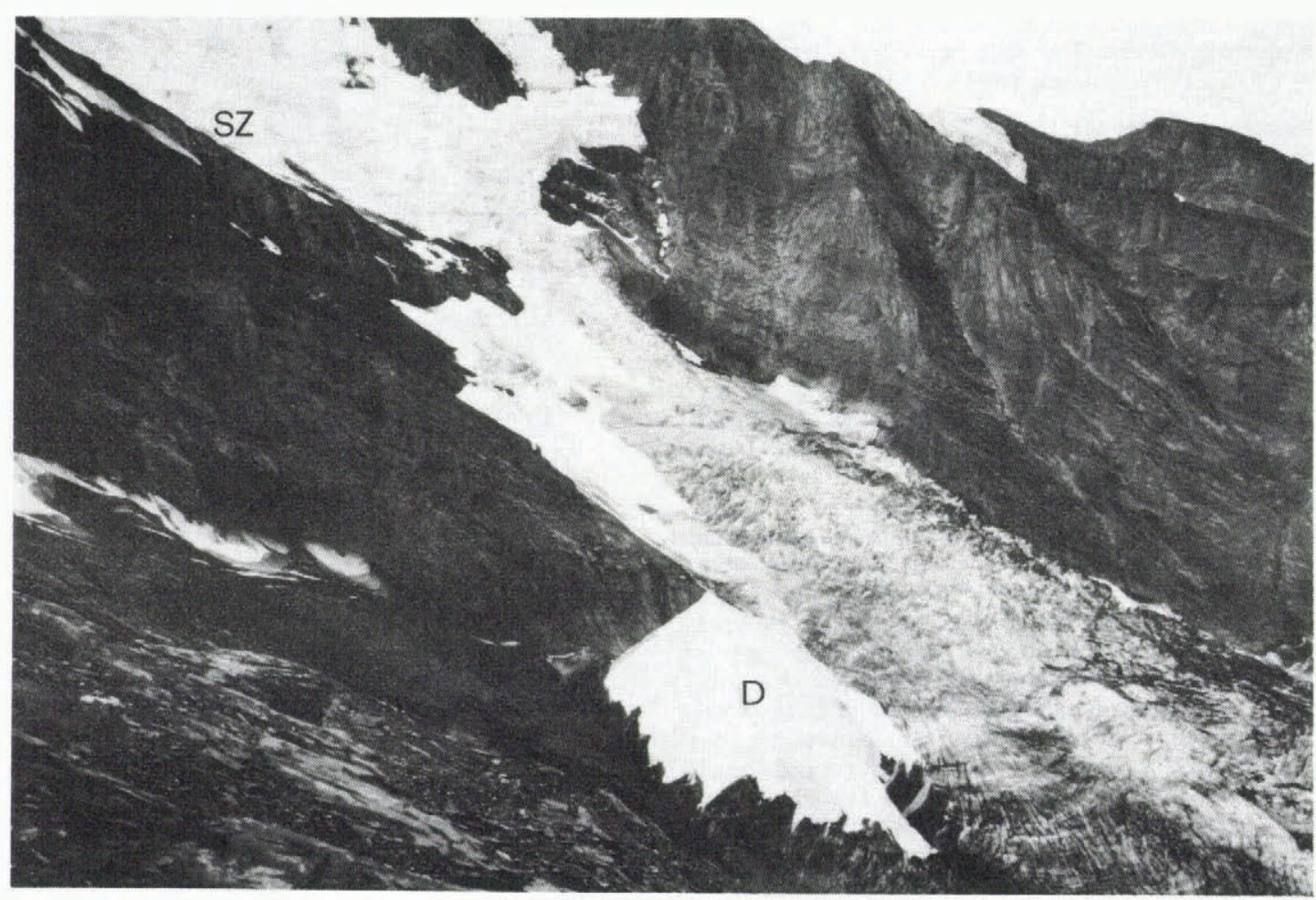

Fig. 6. Starting zone (SZ) and deposits of various ice avalanches (D) on Balmhorngletscher, Gasterental, Switzerland. Aerial photograph 29 August 1983. The starting zone is at $2800 \mathrm{~m}$ a.s.l. (average) and the lowest part of the deposit is at $2150 \mathrm{~m}$ a.s.l.; the deposit is about $850 \mathrm{~m}$ long and has a volume of approximately $2 \times 10^{5} \mathrm{~m}^{3}$. Further avalanching gradually enlarged it to a volume of approximately $3 \times 10^{5} \mathrm{~m}^{3}$ by October 1983. 
glaciers, however, most ice-avalanche data had to be extracted from aerial photographs, and in these cases signs of repeated falls were of ten evident. Nevertheless, no reliable means could be found to establish the volume of the largest individual event. The term "volume" in section 4 and Table III refers to the total volume of all individual events which contributed to an avalanche deposit.

Sequential falls have another disturbing effect which is most difficult to quantify; the first avalanche can fill up crevasses or smooth out rugged pre-glacial moraine fields, thereby considerably altering the path characteristics for subsequent falls. In one particular case (Gamchigletscher, northern Bernese Alps), an avalanche of about $2 \times 10^{4} \mathrm{~m}^{3}$ volume descended over an older and much larger deposit of about $6 \times 10^{5} \mathrm{~m}^{3}$ volume. The reach of the smaller avalanche $(1450 \mathrm{~m})$ was only $15 \%$ shorter than the reach of the bigger one $(1700 \mathrm{~m})$. This effect is well known to some Alpine climbers who expect later avalanches to reach even further than previous ones on heavily crevassed glaciers.

Some important connections between ice-avalanche parameters can be summarized as follows:

(1) Inspection of Table III and Figure 7 shows that the reaches of the largest ice avalanches are the greatest and

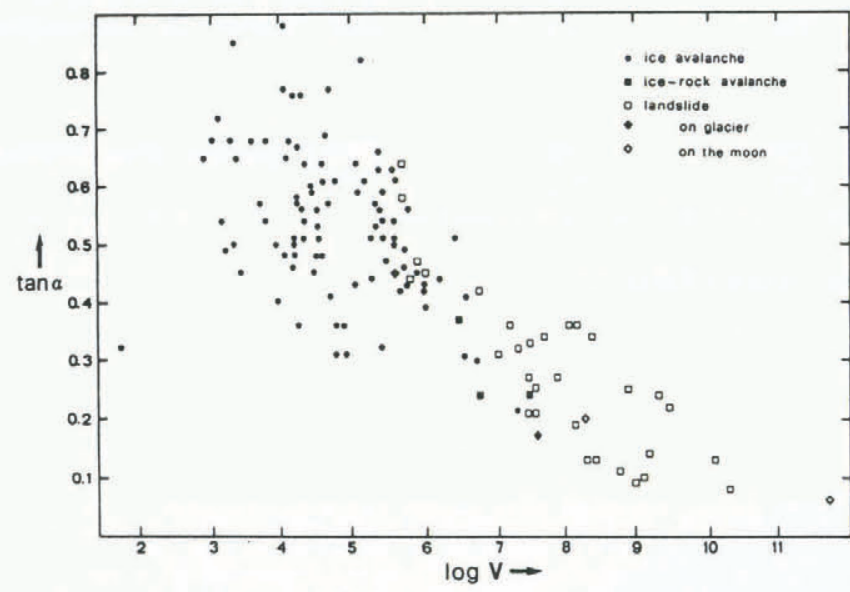

Fig. 7. Tangent of average slope angle ( $\alpha$ ) of ice avalanches and landslides as a function of the logarithm of volume $\left(V\right.$ in $\left.\mathrm{m}^{3}\right)$.

their average slope angles $(\alpha)$ are usually small. Figure 7 also illustrates that ice avalanches of $10^{5.5}-10^{7} \mathrm{~m}^{3}$ have somewhat smaller average slope angles than landslides of equivalent volumes. As with landslides, only a considerable increase in the avalanche volume seems to lead to a significantly smaller average slope angle (logarithmic horizontal axis of Figure 7 !). On the other hand, extremely small slope angles are found with a few ice avalanches also with smal volumes. These events are discussed in section 4.4.

(2) The variation in $\alpha$ is larger for avalanches with small volumes and considerably exceeds the variation for landslides. Irregularities in the topography are thought to have a greater influence on small ice avalanches than on large ones. (3) It seems that frequent or abrupt changes of slope or horizontal direction have a "braking effect" on an ice avalanche. Path sections with an abrupt decrease in slope may affect the avalanche either directly by increasing the friction (as suggested for landslides by Scheller (unpublished) and for snow avalanches by Perla and others (1980)) or indirectly by reducing the moving avalanche's volume due to deposition of some ice on flatter terraces. For example, more than half of the $1.5 \times 10^{6} \mathrm{~m}^{3}( \pm 50 \%)$ volume of the 1977 ice avalanche from the Weisshorn was deposited on large terraces in the upper half of the path (cf. Fig. 8).

(4) Avalanches which first descend over particularly steep terrain seem to have relatively large average slope angles (i.e. comparatively small reaches). This can be explained if it is assumed that greater avalanche velocities lead to greater frictional dissipation of kinetic energy. It therefore seems justifiable to include a velocity-dependent frictional parameter in a model of ice-avalanche motion.

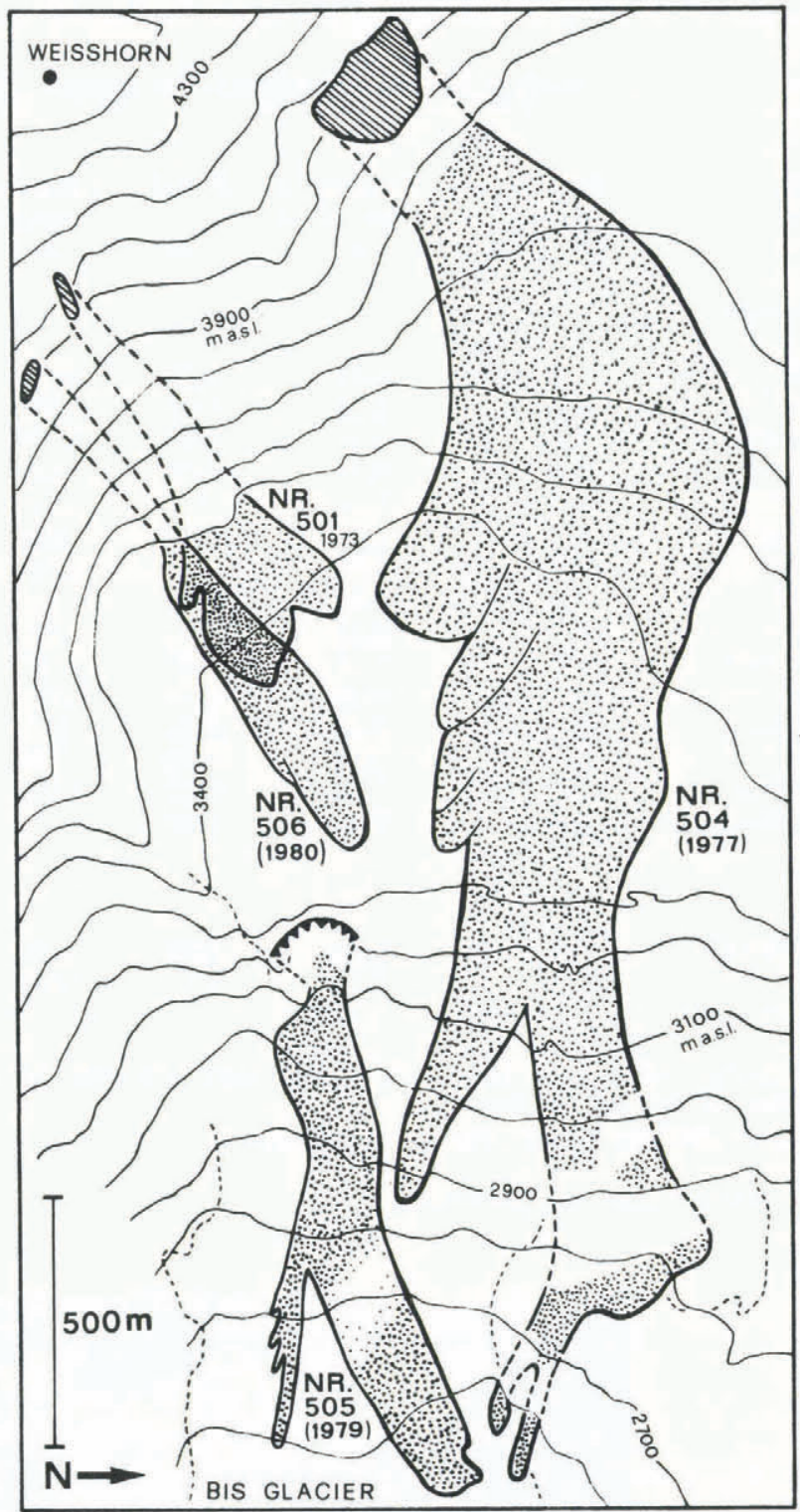

Fig. 8. Ice avalanches Nr. 501, 504, 505, and 506 (numbers refer to data set in Alean (1984)) on Bisgletscher, Valais, Switzerland. Starting zones are hatched and deposits are stippled. Avalanche 505 originated at a type II starting zone, the others at type IB starting zones. The volumes of the ice avalanches are: $1.4 \times 10^{5} \mathrm{~m}^{3}(\mathrm{Nr} .501), 1.5 \times 10^{6}$ $\mathrm{m}^{3}$ (Nr. 504), $4.1 \times 10^{5} \mathrm{~m}^{3}$ (Nr. 505), and $6.0 \times 10^{4} \mathrm{~m}^{3}$ (Nr. 506). Margins of glacierized areas are shown by thin dashed lines.

4.3. One- and two-parameter models used for ice-avalanche motion

The analysis of ice-avalanche parameters leads to the hypothesis that a two-parameter model of avalanche motion might allow a more accurate prediction of run-out distance than the simple concept of volume-dependent average slope angles. To test this hypothesis, 19 well-documented ice avalanches were selected for model calculations. "Turbulent friction" (caused by mutual collisions of ice lumps) was expected to have a minor effect only on very short path where only moderate speeds can occur and where the ice mass is only incompletely shattered into small pieces. Therefore, avalanches with reaches of less than $800 \mathrm{~m}$ were not chosen. Also, all test avalanches had volumes larger than $18000 \mathrm{~m}^{3}$

For the two-parameter model (velocity-independent coefficient of sliding friction: $\mu ; v^{2}$ proportional parameter $M / D$ ) the equations presented by Perla and others (1980) were used. The avalanche paths were approximated by linear segments roughly $100 \mathrm{~m}$ long. Since large steps in the 
avalanche path seem to reduce the avalanche reach, a velocity reduction was applied between adjacent path segments if the lower segment had a smaller inclination than the previous one (cf. Perla and others, 1980). This procedure implies a totally inelastic impact of the avalanche on the path at artificially abrupt slope changes. The problems of such a correction have been discussed by Perla and others (1980) and by Alean (1984). Details of the calibration of the two-parameter model with the 19 test ice avalanches have been given by Alean (1984). Different to the procedure employed by Perla and others (1980), parameters were sought which led in most cases to an overestimation of run-out distances. These "safe" parameters were adjusted in such a way that, when modelling the 19 test avalanches, 17 model avalanches (approximately 90\%) overshot the actual stopping position. In order to determine the additional distances travelled by the model avalanches, the model avalanche tracks were artificially lengthened by straight lines of identical inclinations (horizontal, rising with slope 0.1 and falling with slope 0.1 ). The average additional distance travelled by the model avalanches was considered to be a measure of the model's accuracy and an indication of the necessary "safety zones" required when making actual predictions of stopping positions.

Even taking into account the large average horizontal reach of $2033 \mathrm{~m}$ for the test avalanches, the average additional distances travelled by the model avalanches are disappointingly high (typically hundreds of meters; in extreme cases up to several kilometers). Using only a oneparameter model (mass-dependent but velocity-independent coefficient of sliding friction combined with a "prediction curve" of $90 \%$ safety; cf. Scheidegger, 1973) leads to only slightly worse predictions of run-out distances (Alean, 1984). Reasons for the poor improvement of predictions of run-out distance when using the two-parameter model instead of the one-parameter model are thought to be, in particular, (a) poorly known volumes of the major fall, (b) inability of the model to simulate different path characteristics such as type of surface and lateral spread, and (c) mass loss on flat terraces.

\subsection{Estimating maximum reaches with terrain parameters}

Sometimes the expected reach of ice avalanches is only a few hundred meters. In such a case, an estimation of the reach might best be carried out using empirical terrain parameters, since "turbulent friction" may not fully develop on such a short path (particles are still too large and too few). This method may even be employed for longer avalanche paths as a first approximation of the reach, particularly until a reliable two-parameter model for ice avalanches is available.

A classification of terrain parameters allowed a dis-

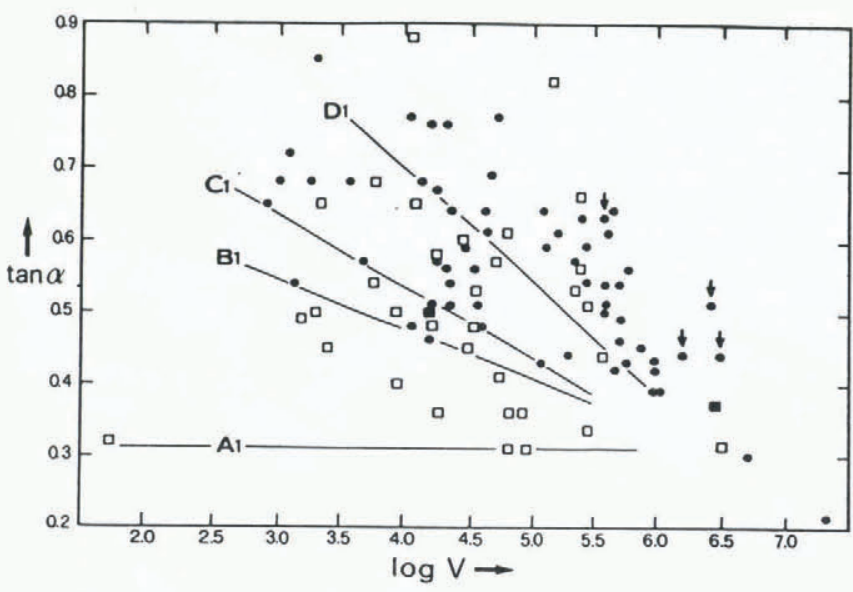

Fig. 9. Grouping of average slopes (tan $\alpha$ ) of ice avalanches with sets of terrain parameters. Al, BI, Cl, and DI are sets of criteria listed in Table IV. Only symbols of avalanches which do not satisfy certain sets of criteria appear below the respective line. Squares show avalanches with more than $60 \%$ of the path over firn with no or few crevasses. Solid squares represent mixed ice/rock avalanches. Solid circles represent other ice avalanches. Arrows point to avalanches which descended over strongly terraced terrain (criteria E1; cf. Table IV). $V$ is volume in $\mathrm{m}^{3}$.

tinctive grouping of the points in Figure 9, which shows average slopes and volumes of ice avalanches. In particular it can be seen that all ice avalanches with very small average slopes and relatively small volumes are those which descended over smooth (mostly crevasse-free) firn surfaces In fact, parts of some of these avalanches may have slid over the firn as compact masses of interlocked ice debris. Such heaps scar the firn surface and produce distinctive trails which show that the mode of motion must be sliding only and definitely not "turbulent" (cf. Fig. 10; Alean, in press).

Table IV lists the criteria (A1, B1, C1, D1, and E1) by which the average slopes were grouped. The volume range over which these criteria are valid had to be limited depending on the number of ice avalanches available for calibration. The straight lines in Figure 9 each correspond to one set of criteria. The significance of the lines is as follows. Of all the known ice avalanches, only those which satisfy the respective set of criteria had average slopes smaller than indicated by the line at a given volume. In

\section{TABLE IV. GROUPING OF AVERAGE SLOPES}

\section{Criteria}

A1 $\log V>6$

B

More than $60 \%$ of path over firn, with few or or no crevasses; $B<1100 \mathrm{~m} ; Q<70 \mathrm{~m}$

$$
\begin{array}{lll}
\mathrm{Cl} & R<1100 \mathrm{~m} ; Q<100 \mathrm{~m} & 3.0<\log V<5.0 \\
\mathrm{D} 1 & R<1500 \mathrm{~m} ; Q<250 \mathrm{~m} & 3.7<\log V<5.7
\end{array}
$$

Volume range of validity

$V$ in $\mathrm{m}^{3}$
Equation of line in Figure 9

$V$ in $\mathrm{m}^{3}$ $\tan \alpha=0.930-0.0998 \log V$

$\tan \alpha=1.327-0.157 \log V$

E1 Large terraces, also in the uppermost third of the path

$V$ Avalanche volume.

$R$ Reach of avalanche.

$Q$ Maximum distance of avalanche path from an oblique line (slope 0.5 ) drawn from the top of the starting zone and above the avalanche path (cf. Fig. 5). Large $Q$-values are assumed to indicate high avalanche velocity. 


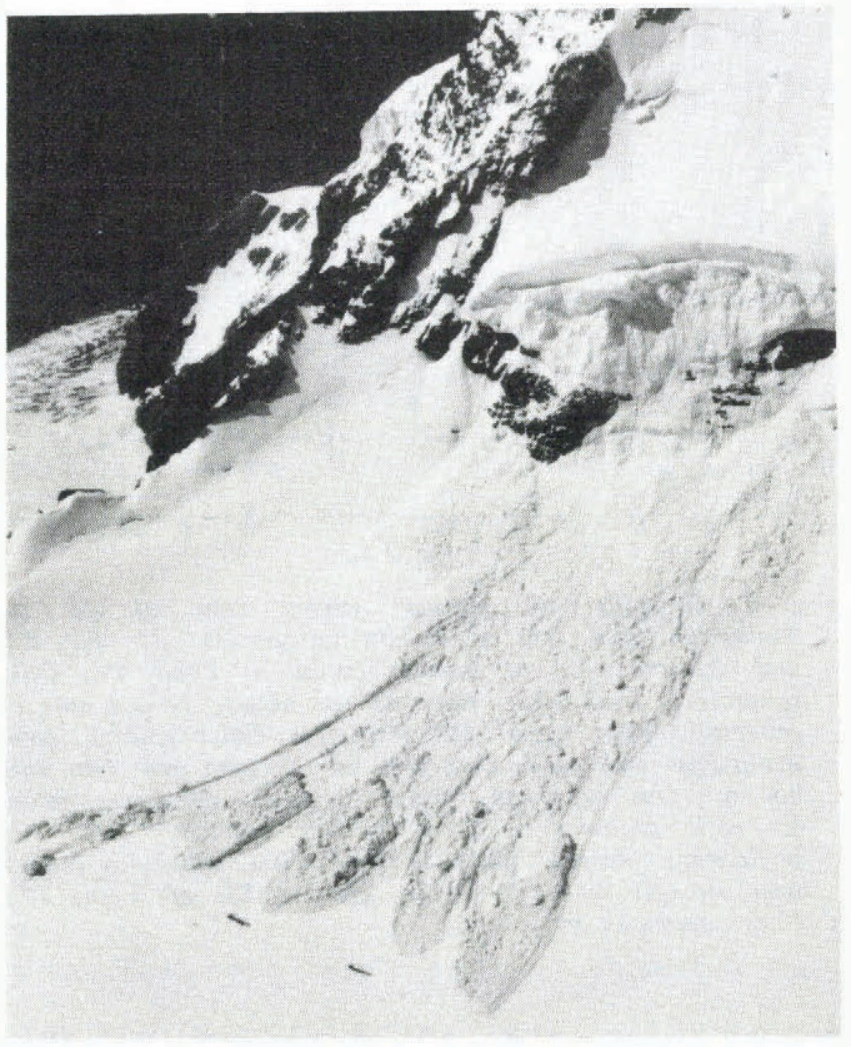

Fig. 10. Ice avalanche from the southern hanging glacier of the Mönch, Bernese Alps, Switzerland. Aerial photograph 6 July 1984; date of fall 5 July 1984. The avalanche has a volume of approximately $3 \times 10^{5} \mathrm{~m}^{3}$ and a reach of $690 \mathrm{~m}$. Compact masses of ice debris show distinctive signs of exclusively sliding ("non-turbulent") motion. The largest individual ice blocks have diameters of up to $15 \mathrm{~m}$ and volumes around $10^{3} \mathrm{~m}^{3}$.

other words, if an avalanche with a particular volume is not expected to satisfy certain sets of criteria, its slope can be expected to be larger than that indicated by the corresponding line in Figure 9.

Only four avalanches are known which satisfy criterion E1 (marked in Figure 9 by arrows pointing down). Therefore, no reliable line could be drawn for this criterion. El applies to avalanches with paths which go over terraces hundreds of meters wide (measured in the direction of the avalanches' motion), where considerable deposition occurs. Criteria sets $\mathrm{B} 1, \mathrm{Cl}$, and $\mathrm{Dl}$ take into account, in particular, the effect of increased "turbulent" friction at high speeds (indicated by a large $Q$-parameter; explanation of this parameter can be found in Table IV and Figure 5).

Only those ice avalanches with volumes smaller than a few million $\mathrm{m}^{3}$, which descended generally over smooth, mostly crevasse-free firn surfaces, had average slopes smaller than that indicated by line B1 but never smaller than the constant slope angle $\alpha$ of $17^{\circ}(\tan \alpha=0.3)$. The somewhat surprising volume indifference of extremely small average slopes is discussed in more detail by Alean (in press).

\section{SUMMARY AND CONCLUSIONS}

Ice avalanches originate in steep parts of glaciers called starting zones. These zones can either be (a) on bedrock (or in rare cases firn) surfaces up to hundreds of meters long and wide and with a rather uniform inclination (type I), or (b) on abrupt slope changes of the bedrock (type II) over which the ice forms a roughly vertical cliff from which lamellae break off. The largest documented ice avalanches, with volumes of up to $10 \times 10^{6} \mathrm{~m}^{3}$ or perhaps even $20 \times 10^{6} \mathrm{~m}^{3}$, are known to have originated in type I starting zones. The maximum ice volumes released in type II starting zones seem to be smaller (at most a few hundred thousand $\mathrm{m}^{3}$ ). The bedrock inclination of type I starting zones seems to be related to altitude, possibly via temperature effects. However, many glaciers, existing on even steeper slopes, have not produced any known ice avalanches.

Alpine type IA starting zones (on which most ice is not frozen to the bedrock) appear to produce ice avalanches primarily from July onwards until October. Intensified mass flux into the starting zone as a result of spring and early summer maximum ice velocity, coupled with destabilizing processes (such as higher ice velocities, intensified crevassing, and the disappearance of marginal ice frozen to the bedrock during the cold season), may lead to this seasonal maximum of ice-avalanche occurrence. On the other hand, no such annual variation in ice-avalanche activity from type IB starting zones (most or all ice frozen to the bedrock) and from type II starting zones was found. Here, mechanical failure within the ice seems to be the dominant release mechanism as opposed to slipping on the bedrock as in type IA starting zones.

Maximum ice-avalanche reaches can, to some extent, be estimated with two-parameter models such as the ones used for dry-snow avalanches. The main difficulty lies in the calibration of the parameters as a function of the avalanche volume. Volumes of individual falls are rarely known accurately because of successive falls which build up one deposit. Also, successive falls considerably change the terrain characteristics by filling up crevasses and other relatively small terrain irregularities. On terraced terrain, massive deposition of ice may start almost immediately below the starting zone. When applied to such ice avalanches, models such as those used by Voellmy (1955), Salm (1966), or Perla and others (1980) are drastic simplifications of the real process.

When predicting the reach of new ice avalanches, errors in the order of several hundred meters have to be expected if the reach is in the order of about $2 \mathrm{~km}$. On relatively short paths, the simpler method of estimating the average slope angle of the expected avalanche may be an equally effective and accurate method of estimating the reach. Simple terrain parameters can be used as a tool to limit the variation of slope angles which have to be expected.

It should be realized that the results of this study are based on fewer events than comparable investigations of snow-avalanche release mechanisms and run-out distances. The accuracies of important empirical critical parameters such as slopes of starting zones and avalanche paths are poor and make predictions particularly delicate in cases when a village or other permanent structure is already suspected to be within or near the edge of a danger zone. Further documentation of starting zones and run-out distances, especially in connection with precisely known volumes of individual falls, will be of considerable importance to further improvement or refinement of the parameters described in this study.

\section{ACKNOWLEDGEMENTS}

Professor Dr D. Vischer, Director of the VAW (Versuchsanstalt für Wasserbau, Hydrologie und Glaziologie, ETH-Zürich) supported this study. Dr B. Salm and $\mathbf{H}$. Frutiger (Eidgenössisches Institut für Schnee- und Lawinenforschung, Weissfluhjoch, Davos) made valuable suggestions in connection with avalanche dynamics. Professor $\operatorname{Dr}$ H. Röthlisberger, Dr W. Haeberli, and $\mathrm{Dr}$ K. Hutter also critically read the manuscript. P. Alean (VAW), S Baumann, F. Gabriel, W. Schmid (VAW), and H. Egeter participated in the field work. L. Mayo (USGS, Fairbanks) made available aerial photographs from Alaska. P. Alean helped by editing the English.

\section{REFERENCES}

Aellen, M., and Iken, A. 1979. Variationen der Gletscherbewegung. Mitteilungen der Versuchsanstalt für Wasserbau, Hydrologie und Glaziologie an der Eidgenössischen Technischen Hochschule (Zürich), Nr. 37, p. 111-26.

Alean, J. 1984. Untersuchungen über Entstehungsbedingungen und Reichweiten von Eislawinen Mitteilungen der Versuchsanstalt für Wasserbau, Hydrologie und Glaziologie an der Eidgenössischen Technischen Hochschule (Zürich), Nr. 71. 
Alean, J. 1985. Ice avalanche activity and mass balance of a high-altitude hanging glacier in the Swiss Alps. Annals of Glaciology, Vol. 6, p. 248-49.

Alean, J. In press. Ice avalanches and a landslide on Grosser Aletschgletscher, Bernese Alps, Switzerland. Zeitschrift für Gletscherkunde und Glazialgeologie.

Bakkehøi, S., and others. 1981. On the computation of parameters that model snow avalanche motion, by $\mathrm{S}$. Bakkehøi, T. Cheng, U. Domaas, K. Lied, R.I. Perla, and B. Schieldrop. Canadian Geotechnical Journal, Vol. 18, No. 1, p. 121-30.

Bakkehøi, S., and others. 1983. Calculation of snow avalanche runout distance, by S. Bakkehøi, U. Domaas, and K. Lied. Annals of Glaciology, Vol. 4, p. 24-29.

Capello, C.F 1959. Frane-valanghe di ghiaccio nel gruppo del Monte Bianco. Bollettino del Comitato Glaciologico Italiano, No. 8 - II Ser. 1957-1958. Parte prima, p. 125-38.

Coaz, J. 1910. Statistik und Verbau der Lawinen in den Schweizeralpen. Bern, Eidgenössisches Departement des Innern, p. 20-25.

Davies, T.R.H. 1982. Spreading of rock avalanche debris by mechanical fluidization. Rock Mechanics, Vol. 13, No. 1, p. 9-24.

Glaister, R.M. 1951. The ice slide on the Glacier du Tour. Journal of Glaciology, Vol. 1, No. 9, p. 508-09.

Haeberli, W. 1975. Überwachung von Kalbungsflutwellen am Grubengletscher. Schweizerische Bauzeitung, Jahrg. 93, Ht. 43, p. 694-96.

Haeberli, W. 1976. Eistemperaturen in den Alpen. Zeitschrift für Gletscherkunde und Glazialgeologie, Bd. 11, Ht. 2, 1975, p. 203-20.

Haeberli, W. 1983. Frequency and characteristics of glacier floods in the Swiss Alps. Annals of Glaciology, Vol. 4, p. 85-90.

Haeberli, W., and Alean, J. 1985. Temperature and accumulation of high altitude firn in the Alps. Annals of Glaciology, Vol. 6, p. 161-63.

Haeberli, W., and Röthlisberger, H. 1976. Beobachtungen zum Mechanismus und $\mathrm{zu}$ den Auswirkungen von Kalbungen am Grubengletscher (Saastal, Schweiz). Zeitschrift für Gletscherkunde und Glazialgeologie, Bd. 11, Ht. 2, 1975, p. 221-28.

Haefeli, R. 1966. Note sur la classification, le mécanisme et le contrôle des avalanches de glace et des crues glaciaires extraordinaires. Union de Géodésie et Géophysique Internationale. Association Internationale d'Hydrologie Scientifique. Commission pour la Neige et la Glace. Division Neige Saisonnière et Avalanches. Symposium international sur les aspects scientifiques des avalanches de neige 5-10 avril 1965, Davos, Suisse, p. 316-25. (Publication No. 69 de l'Association Internationale d'Hydrologie Scientifique.)

Heim, A. 1896. Die Gletscherlawine an der Altels am 11. September 1895. Neujahrsblatt der Naturforschenden Gesellschaft in Zürich 98.

Heim, A. 1932. Bergsturz und Menschenleben. Zürich, Fretz und Wasmuth. (Vierteljahrsschrift der Naturforschenden Gesellschaft in Zürich.)

Hsü, K.J. 1975. Catastrophic debris streams (sturzstroms) generated by rockfalls. Geological Society of America. Bulletin, Vol. 86, No. 1, p. 129-40.

Hsü, K.J. 1978. Albert Heim: observations on landslides and relevance to modern interpretations. (In Voight, B., ed. Rockslides and avalanches, 1. Natural phenomena. Amsterdam, etc., Elsevier Scientific Publishing Company, p. 70-93.)

Iken, A. 1977. Movement of a large ice mass before breaking off. Journal of Glaciology, Vol. 19, No. 81, p. 595-605.

Iken, A. 1978. Variations of surface velocities of some Alpine glaciers measured at intervals of a few hours. Comparison with Arctic glaciers. Zeitschrift für Gletscherkunde und Glazialgeologie, Bd. 13, Ht. 1/2, 1977 , p. 23-35.

Körner, H.J. 1976. Reichweite und Geschwindigkeit von Bergstürzen und Fliessschneelawinen. Rock Mechanics, Vol. 8 , No. 4 , p. $225-56$.
Körner, H.J. 1980. Modelle zur Berechnung der Bergsturzund Lawinenbewegung. (In Interpraevent 1980. ... Bad Ischl. Klagenfurt, Forschungsgesellschaft für Vorbeugende Hochwasserbekämpfung, Bd. 2, p. 15-55.

Körner, H.J. 1983. Zur Mechanik der Bergsturzströme vom Huascaran, Peru. Hochgebirgsforschung (Innsbruck), Ht. 6, p. 71-110.

Lied, K., and Bakkehøi, S. 1980. Empirical calculations of snow-avalanche run-out distance based on topographic parameters. Journal of Glaciology, Vol. 26, No. 94, p. 165-77.

Lliboutry, A.E. 1975. La catastrophe de Yungay (Pérou). [Union Géodésique et Géophysique Internationale. Association Internationale des Sciences Hydrologiques. Commission des Neiges et Glaces.] Symposium. Neiges et glaces. Actes du colloque de Moscow, août 1971, p. 353-63. (IAHS-AISH Publication No. 104.)

Morales, B. 1966. The Huascaràn avalanche in the Santa valley, Peru. Union de Géodésie et Géophysique Internationale. Association Internationale d'Hydrologie Scientifique. Commission pour la Neige et la Glace. Division Neige Saisonnière et Avalanches. Symposium international sur les aspects scientifiques des avalanches de neige 5-10 avril 1965, Davos, Suisse, p. 304-15. (Publication No. 69 de l'Association Internationale d'Hydrologie Scientifique.)

Perla, R., and others. 1980. A two-parameter model of snow-avalanche motion, by R. Perla, T.T. Cheng, and D.M. McClung. Journal of Glaciology, Vol. 26, No. 94, p. 197-207.

Röthlisberger, H. 1978. Eislawinen und Ausbrüche von Gletscherseen. Jahrbuch der Schweizerischen Naturforschenden Gesellschaft. Wissenschaftlicher Teil, p. 170-212.

Röthlisberger, H., and Kasser, P. 1978. The readvance of the Allalingletscher after the ice avalanche of 1965. Materialy Glyatsiologicheskikh Issledovaniy. Khronika. Obsuzhdeniya, Vyp. 33, p. 152-64.

Salm, B. 1966. Contribution to avalanche dynamics. Union de Géodésie et Géophysique Internationale. Association Internationale d'Hydrologie Scientifique. Commission pour la Neige et la Glace. Division Neige Saisonnière et Avalanches. Symposium international sur les aspects scientifiques des avalanches de neige 5-10 avril 1965, Davos, Suisse, p. 199-214. (Publication No. 69 de l'Association Internationale d'Hydrologie Scientifique.)

Scheidegger, A.E. 1973. On the prediction of the reach and velocity of catastrophic landslides. Rock Mechanics, Vol. 5, No. 4, p. 231-36.

Scheiwiller, T., and Hutter, K. 1982. Lawinendynamik. Übersicht über Experimente und theoretische Modelle von Fliess- und Staublawinen. Mitteilungen der Versuchsanstalt für Wasserbau, Hydrologie und Glaziologie an der Eidgenössischen Technischen Hochschule (Zürich), Nr. 58.

Scheller, E. Unpublished. Geophysikalische Untersuchungen zum Problem des Taminser Bergsturzes. [Dissertation $\mathrm{Nr}$. 4560, Eidgenössische Technische Hochschule Zürich, 1970.]

Schneider, E. 1983. Begleitworte zur Karte der Gletschersturzmure vom 10. Januar 1962. Hochgebirgsforschung (Innsbruck), Ht. 6, p. 17-29.

Shreve, R.L. 1966. Sherman landslide, Alaska. Science, Vol. 154 , No. 3757 , p. $1639-43$.

Slupetzky, H., and others. 1983. Zur Karte "Nördliches Bockkarkees 1979", 1:10 000, by H. Slupetzky, R. Puruckherr, and C. Hoberg. Zeitschrift für Gletscherkunde und Glazialgeologie, Bd. 19, Ht. 2, p. 163-71.

Stadelmann, J. 1983. Zur Dokumentation der Bergsturzereignisse vom Huascaran. Hochgebirgsforschung (Innsbruck), Ht. 6, p. 51-70.

Voellmy, A. 1955. Über die Zerstörungskraft von Lawinen. Schweizerische Bauzeitung, Jahrg. 73, p. 159-65, 212-17, 246-49, and 280-85.

Welsch, W. 1983. Begleitworte zum Höhenlinienplan 1: 25000 der Bergsturzmure vom Huascaran. Hochgebirgsforschung (Innsbruck), Ht. 6, p. 31-50. 